\title{
Deus após Deus: Uma Tentativa Anateísta de Re-imaginar Deus
}

\section{God after God: An Anatheist Attempt to Re-imagine God}

DOI:10.12957/ek.2015.21846

Dr. Richard Kearney

kearneyr@bc.edu

Boston College - EUA tradução Ms.Maria Helena Silva Soares helenastraub@gmail.com

UERJ

Neste ensaio, Richard Kearney examina a possibilidade filosófica do retorno à noção de Deus após a morte de Deus. Ele chama esta possiblidade de ana-teísmo, sugerindo uma terceira via para além da oposição entre teísmo dogmático e ateísmo. Para este fim, ele explora alguns caminhos: o caminho hermenêutico, inspirado em Paul Ricoeur que falou de um movimento da religião ao ateísmo e à fé; o caminho Messiânico-escatológico de Levinas, Derrida e Benjamin; e a estética de alguns poetas e artistas. $\mathrm{O}$ ensaio investiga a aposta ana-teísta sob três categorias principais: tempo, espaço e imaginação.

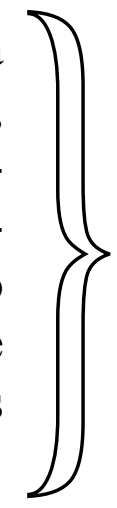

PALAVRAS-CHAVE Anateísmo. Tempo. Espaço. Imaginação. Hermenêutica

Richard Kearney examines the philosophical possibility of returning to the notion of God after the death of God. He calls this possibility ana-theism, suggesting a third way beyond both dogmatic theism and atheism. To this end, he explores a number of paths: the hermeneutic path inspired by Paul Ricoeur who spoke of a movement from religion to atheism to faith; the Messianiceschatological path of Levinas, Derrida and Benjamin; and the aesthetic path of a number of poets and artists. The essay investigates the ana-theist wager under three main headings: time, space and imagination.

KEY-WORDS Anatheism. Time. Space. Imagination. Hermeneutic 


\section{Ana: Uma Questão de Tempo}

"Ana" é um prefixo definido no Shorter Oxford English dictionary como: "Subida no espaço ou no tempo; retorno, novamente". Assim entendido, o termo suporta o sentido mais profundo e amplo do "após" contido na expressão “Deus após Deus". O poeta, Gerard Manley Hopkins, descreve o momento da criação imaginativa como "em-seguimento, seguidamente, de-novar" em epifania poética, por conseguinte, como uma recuperação da experiência passada que se move ao futuro, proferindo nova vida à memória, dando um futuro ao passado. O que Hopkins quer dizer com isso, penso, é que certas experiências profundas podem passar por um desencantamento após o qual nós podemos retornar de novo a elas, de novo sob uma nova luz, mais e mais. Como poeta religioso, Hopkins está falando de uma releitura especificamente sagrada. Mas, mesmo ele sendo católico, essa noção de repetição sacramental não está confinada a uma religião particular. Refere-se, sugiro, a qualquer movimento poético de voltar a "Deus após Deus" - Deus, novamente, depois da perda de Deus. Como na brincadeira de criança, "sumiu, achou novamente". "Fort/ $D a$ ". Aprendemos cedo que o que desaparece como literal volta novamente como figural - isto é, como signo e símbolo, como uma segunda presença na e através da ausência. E símbolo aqui não quer dizer falso ou irreal. O retorno do que foi perdido - no caso da religião, a perda de Deus - seja talvez uma das mais reais presenças. De fato, uma presença pode ser muito mais poderosa e comovente por causa, precisamente, do seu retorno por meio da ausência.

Assim, no prefixo ana- encontramos a ideia de recuperar, revisitar, reiterar, repetir. Mas repetir para frente não para trás. Não se trata de regressar nostalgicamente a um passado inocente. A questão é, ao contrário, de voltar "depois" em razão de avançar novamente. Recuar para saltar melhor [Reculer pour mieux sauter]. Então, é neste sentido que uso o termo ana-teísmo como o "retorno à Deus após Deus": a recuperação da hermenêutica crítica das coisas sagradas que se passaram, mas ainda carregam um resto radical, uma potencialidade não realizada ou a promessa de ser mais plenamente realizada no futuro. Desta forma, ana-teísmo pode ser entendido como "pós-fé", que é mais do que um simples "pós-pensamento" ou "pós-afeto". Pós-fé como escatológico - algo

1 Ver discussão sobre isso em: KEARNEY, R., Anatheism: Returning to God after to God, Columbia University Press, New York, 2010, pp.11-12.

N.T. No original: “aftering, seconding, over and overing" Optamos por utilizar a solução proposta por Luís Gonçalves Bueno de Camargo: "No original há o uso de três criações vocabulares, que procurei reproduzir: "oftening, over-and-overing, aftering!" por "a sempridade, o de-novar, o em-seguimento". Cf. CAMARGO, L. Tradução comentada da Poesia e da Prosa de Gerard Manley Hopkins. Campinas, Universidade Estadual de Campinas, 1993, p.195. 
terminado no final, que já estava lá desde o início. E isso porque o após ana também é um "antes". Um antes que tenha sido transposto, por assim dizer, para um segundo depois.

Algumas pessoas interpretam mal o anateísmo como um terceiro termo dialético que substitui o teísmo e o ateísmo. Eles o interpretam como uma espécie de síntese hegeliana ou a resolução final. Mas não o vejo assim. É importante, para mim, que o anateísmo contenha um momento de ateísmo dentro de si. Bem como um momento de teísmo. Ou, devo dizer, o anateísmo pré-contém ambos: para isso, ele opera a partir de um espaço e tempo tanto anterior à dicotomia do ateísmo e do teísmo, quanto posterior. O duplo "a" de anateísmo mantém a promessa, mas não a necessidade de uma segunda afirmação, uma vez que a "morte de Deus" fez esse trabalho. Mas ele difere radicalmente da "negação da negação" de Hegel, que vê o retorno como uma síntese ou superação (Aufhebung). Meu argumento é que o momento de "ana" é atualmente um risco e uma aposta - um drama perigoso que pode seguir de qualquer maneira. E também pode dar errado. Cabe a nós. É uma questão de discernimento e de decisão de nossa parte. $\mathrm{O}$ evento não se passa às nossas costas, independentemente da nossa vontade, como teodiceia ou a dialética do Espírito Absoluto de Hegel. Não há “Artimanha da Razão" (Ruse of Reason). O anateísmo não é uma dialética inevitável, levando a uma Totalidade Última. Não se trata de Divindades Maiúsculas: Deuses Alpha e Omega. Ao contrário! [Au contraire!] Anateísmo é sobre re-imaginar - e re-existir - o sagrado no menor destes. É o menor caso do início ao fim.

O anateísmo concentra-se, portanto, sobre possibilidades não realizadas ou suspensas que são mais poderosamente reanimadas se também experimentam um momento de a-teísmo; o "a-" aqui é um gesto de abstenção, de privação, de retirada ${ }^{2}$. Um momento que é menos frequentemente uma questão de teo-

2 Ricoeur reconheceu a passagem indispensável para o ateísmo (pelo menos para nós, motdernos) no caminho do que ele chamou de um novo tipo de "fé pós-religiosa". Mas o drama do ateísmo no cerne do anateísmo não é uma questão de ir através do ateísmo desde uma fé religiosa primária até uma segunda fé religiosa, o que poderia ser visto como um somatório triunfalista último. Ana-teísmo é o movimento para além da ingenuidade da primeira fé - das certezas infantis, suposições fáceis, pressupostos ou dogmas adquiridos - para um espaço aberto de possibilidades. Uma Abertura que pode levar tanto a uma escolha do ateísmo ou do teísmo após o ateísmo. Este é o espaço ou tempo do anateísmo e ele está sempre aberto - sem o ateísmo ou o teísmo pode-se presumir ter certeza por si mesmo, sem cair de novo em outro dogmatismo (de crença ou anti-crença). Então, se isso é uma questão do que chamo "ateísmo anateísta" ou "teísmo anateísta" - um segundo teísmo ou um segundo ateísmo - é para nós escolhermos: é uma aposta, uma tarefa hermenêutica. O momento anateísta deve ser entendido, por conseguinte, como o momento anterior a uma escolha entre o teísmo e o ateísmo, na medida em que liberta a aposta, a ação e o compromisso. E, neste sentido, ele surge "depois" que abandonamos as prisões dogmáticas do primeiro teísmo ou do primeiro ateísmo. Na passagem da religião até o ateísmo à fé, o momento hermenêutico da "suspensão" é indispensável. Ou, para colocar em termos do cír- 
ria epistemológica, dogma, credo ou proposição, do que uma experiência pré-reflexiva vivida da perdição comum e solidão, um sentimento de Angústia ou abandono, de uma existencial "noite escura da alma" - e quem nunca provou tais momentos? Este momento privativo - o primeiro "a" - é indispensável para o anateísmo. Mas, em "a-n-a" temos dois A's. E se o primeiro "a" é o "a" de a-teísmo, o segundo "a" é o "não" do "não". A negação da negação. O duplo A-A do anateísmo. A reabertura para algo novo. Depois de tudo.

Então, repito, ana- não é uma garantia de progresso inelutável ou otimismo cego. Não é apenas algo que surge na esteira do colapso religioso, mas também algo que nos traz de volta ao começo - a um passado anterior à divisão entre teísmo e ateísmo. E neste sentido, penso na leitura afirmativa de Kierkegaard da 'repetição' como um reviver do presente passado. Esta repetição do primeiro como último, do anterior como posterior, significa para Kierkegaard a recuperação do evento de fé não como uma regressão a uma posição original, mas como uma disposição originária de abertura radical ao Outro. O que ele chama de um 'salto de fé' em Temor e Tremor'. Abraão tem de perder seu filho como um dado, a fim de recebê-lo de volta como um dom; ele tem que abandonar Isaque como posse, a fim de recebê-lo de volta como promessa. Isaque não é seu (como extensão, aquisição, projeção), mas de outros, outro, um Outro (um dom de retorno que Kierkegaard chamou de 'Absoluto'). Em suma, é uma questão de repetir para a frente ao invés de para trás, uma segunda recuperação de algo depois que você o perdeu. Isto vai além do tempo cronológico - ou seja, a noção de diferentes momentos sucedendo uns aos outros de forma linear do passado ao presente para o futuro - em favor do tempo kairológico, um tempo fora do tempo concentrando-se em um momento de epifania (Augenblick) da graça, onde a eternidade atravessa o instante ${ }^{4}$. Assim, 'ana' é um prefixo que procura captar este enigma do passado-como-futuro, antes-como-depois ${ }^{5}$.

culo hermenêutico de Paul Ricoeur, a menos que se aceite que os "mestres da suspeita" - Freud, Marx, Nietzsche (e eu acrescentaria De Beauvoir e a crítica feminista) - desmascararam o corpus teológico herdado, há menos chances de alcançar uma fé digna de ser vivida, intelectualmente falando. Esses ateus iconoclastas podem ser considerados aliados no processo da suspeita hermenêutica que pode levar, por sua vez (para aqueles que assim escolheram), a uma reafirmação hermenêutica do sagrado. Ver: RICOEUR, P. The Symbolism of Evil, Trad. E. Buchanan, Beacon Press, Boston, 1968. e Idem, Relgion, Atheism, Faith. in: The Conflict of Interpretations, ed. D. Ihde, Northwestern University Press, Evanston, 1974, pp. 440-467.

3Cf. KIERKEGAARD, S., Fear and Trembling, Transl. by A. Hannay, Penguin, New York, 1985.

4Neste sentido, Cristo pode dizer "Antes de Abraão, eu sou" e "Lembra de mim até que eu venha".

5 Penso que muitos pensadores depois de Kierkegaard - tal como Benjamin, Derrida e Agamben - estão dizendo algo similar quando falam de "tempo messiânico". (Embora eu, pessoalmente, prefira a noção de tempo "kairológico" ou "escatológico"). Este tempo-ana traduz o enigma sagrado do Reino que já foi, é agora e ainda está por vir. Está sempre pronto e está sempre por vir. 
Dizer isso não é, contudo, negar que ana também envolve tempo histórico. Tempo infinito é in-finito, ele atravessa a temporalidade finita e não pode existir sem ela. Como entendo, o ana-teísmo em sua manifestação corrente, de fato, coincide com uma situação histórica concreta, que vem depois da morte de Deus, cultural, social e intelectualmente. Ele é marcado pelas declarações de Nietzsche, Marx e Freud, pelas polêmicas ateístas do Esclarecimento (Enlightenment), a Revolução Francesa, a crítica moderna da religião como ideologia e assim por diante. $\mathrm{O}$ anateísmo manifesta uma ansiedade moderna típica frente ao que Max Weber chamou de: "desencantamento" do mundo, a dessacralização da sociedade, o mal-estar geral do abandono de Deus, a perda da fé, etc. Neste sentido, anateísmo é de fato um fenômeno histórico-cultural que se relaciona com a nossa cultura humanista secular contemporânea. Mas não de uma maneira teleológica - a ideia de que éramos ignorantes e agora vimos a luz: toda a fé era uma ilusão, mas finalmente alcançamos o 'fim' da religião e estamos livres, enfim! Em suma, ele não é conivente com o atual esquadrão anti-Deus de Richard Dawkins, Christopher Hitchens, Sam Harris ou com a hybris neo-liberal de Fukuyama. Para mim, ter perdido a ilusão de Deus (como superintendente soberano do universo) é aproveitar a possibilidade de abrir-se, mais uma vez, à promessa original e duradoura de um Estrangeiro sagrado, um Outro absoluto, que vem como um dom, um chamado, uma convocação, como um convite à hospitalidade e à justiça. Em resumo, anateísmo é uma abertura radical para alguém ou algo que foi perdido e esquecido pela metafísica ocidental - para citar Heidegger e Derrida ${ }^{6}$ - e precisa ser recordado novamente. E aqui, penso, podemos traduzir a partir da formulação histórica da questão anateísta - o que vem depois do desaparecimento de Deus? - para uma mais existencial: como pode qualquer auto-experiência contemporânea estar em seu/ sua existência vivida concreta? Ou seja, ser pessoal em oposição ao impessoal?

6Há um certo momento desconstrutor em Emmanuel Levinas e Jacques Derrida, entre outros, que tem muito a nos ensinar. Levinas fala sobre ateísmo em Totalidade e Infinito como o maior presente que o Judaísmo deu à humanidade. O que eu acho que ele quer dizer é que o Judaísmo é uma proibição profética contra ídolos e ilusões; esse messianismo promissor sinaliza um momento ateísta da "separação" da fusão com o ser, incluindo a fusão com Deus (paganismo sacrificial); e aquela separação dada pelo "Eu", o mesmo, uma liberdade e uma responsabilidade para responder ao outro, o estranho. Se não existir essa separação "ateísta", não pode haver nenhum encontro ético com o estranho, que, Levinas argumenta, carrega o rosto dos feridos, dos destituídos, dos nus - "a viúva, o órfão, o estranho" - que é, em si, para Levinas, o "rastro de Deus". Derrida, por sua vez, fala sobre uma "religião sem religião". E se há uma diferença entre Derrida e mim, é uma diferença entre "sem" (sans de Derrida) e "após" (ana). Eu falo sobre religião após a religião, onde ele fala sobre religião sem religião. Mas como ele mesmo disse em sua reflexão sobre meu "Deus-do talvez" (Peut-être), não há senão a "mais fina das diferenças", por vezes, entre seu ateísmo e meu anateísmo. Conferir meu Diálogo com Derrida, intitulado Terror, Religion and the New Politics que teve lugar na Universidade de Nova York, em outubro de 2001, e foi publicado em KEARNEY, R. Debates in Continental Philosophy: Conversations with Contemporary Thinkers, Fordham University Press, New York, 2004, pp. 3-15. Ver também meu ensaio relacionado Derrida's Messianic Atheism, in E. Baring and P. Gordon (ed.), The trace of God: Derrida and Religion, Fordham University Press, New York, 2014. 
Por isso, tento voltar constantemente a 'exemplos' e 'testemunhos' do momento anateísta. Para descrições - bíblicas, literárias, depoimentos - de abandono vivido, desilusão, desorientação, seguidos de momentos de voltar-se novamente (o que Sócrates chamava periagoge, o que Agostinho chamava conversão). O momento negativo de deixar ir é indispensável. Ele é a chave para uma apreciação adequada do anateísmo. Sem isso, temos graça barata [cheap grace] - Deus como ilusão reconfortante, solução rápida, ópio do povo. Muitas vezes penso aqui nas místicas 'noites escuras da alma', do sentido de alienação radical de Dostoievski, dos sonetos escuros de Hopkins ("I wake and feel the fell of dark, not day!'), ou do abandono de Cristo, pelo Pai, na cruz'. Estes são todos os momentos concretos de esvaziamento radical que sinalizam um retorno ao momento inaugural do anateísmo: a aposta de sim ou não para o Estrangeiro. Esta aposta primordial é antes de tudo uma aposta existencial não puramente lógica à Pascal (que é mais como uma aposta do conhecimento, epistemológica em vez de ontológica). Afirmo que esta aposta anateísta - para transformar a hostilidade em hospitalidade - é o momento inaugural de todas as grandes tradições de sabedoria. Embora, admito, tendo em Anateísmo a focar principalmente sobre a tradição Abraâmica em que cresci - tentando reimaginar certas 'cenas primordiais' de hostilidade-hospitalidade, revisitando as apostas inaugurais das narrativas bíblicas - ou seja, Abraão e Sara como eles encontram estrangeiros em Mamre; Maria confrontada com o estrangeiro chamado Gabriel; Muhammad confrontado com uma voz na caverna. Mas isso me traz já a minha segunda questão - anateísmo como um ato de re-imaginação ${ }^{8}$.

7Ler anateísticamente, a Cruz não é um sacrifício expiatório por um sanguinário, Deus patriarcal, empenhado em resgatar seu filho pelos nossos pecados. É um momento de superação como uma tentação "teísta" injuriosa em um momento "ateísta" de deixar ir, de modo a abrir uma disposição "anateísta" para o novo, o surpreendente, o gracioso, o dom - a vida ressuscitada. Uma descoberta ainda mais radical de Deus após Deus (concebido como o Alpha-Deus da teodiceia). E eu digo "mais um", pois, como o próprio Cristo revelado, vem acontecendo desde o início e nunca vai acabar: "Antes de Abraão, eu sou" e "agora, eu preciso ir para que o Paráclito possa vir". Cristo-aqui-e-agora é sempre Cristo-antes-e-depois: ana-crônico, ana-Cristo. Em outras palavras, na cruz e em todas as suas feridas humanas, Cristo abandona o Deus Pai Onipotente, que o abandonou. Sua lição definitiva derradeira é uma kenosis radical, deixando para trás as afeições e as ilusões perdidas, de modo a abrir-se para o novo, o outro, o estranho. "Meu Deus, meu Deus, por que me abandonaste?" esse momento ateísta de negação e de capacidade negativa que abre o espaço para uma libertação e uma liberação para uma nova vida para além da vida antiga - "A ti confio meu espírito". Neste retorno anateísta, Cristo confia-se ao "ti" de cada Deus após Deus, todo estranho que procura ou recebe comida e amor, como anunciado em Mateus 25 - os seus discípulos com fome na Galileia ("venham e tomem café da manhã"), Maria Madalena no jardim do sepulcro ("Miriam!"), seus companheiros de viagem na estrada de Emaús. Cristo continua a voltar (ana) a seus seguidores depois (ana) de os deixar, como um hóspede que não reconhecem - até que ele os receba com comida e toque. Apenas como convidados novamente (ana) é que eles reconhecem o hospedeiro divino.

8 Considerada anateísticamente, a Bíblia é um campo de batalha de interpretações, um local de intermináveis conflitos de interpretação entre hostilidade e hospitalidade. Não é preciso recitar a longa ladainha de hostilidades que têm sido travadas - e sofridas - pelas três religiões 


\section{Re-imaginar Deus - Uma Questão de Ficção}

'Ana' não é só uma questão de retornar no tempo, mas também no espaço. Envolve um topos, assim como um kairós. Necessita de imagens. Quando se trata de re-imaginar o sagrado, viajo pelo terceiro dos três caminhos que esbocei no meu livro Anatheism (filosófico, religioso e poético) - a saber, o caminho da imaginação poética9 .

Interesso-me pela re-imaginação do sagrado como um espaço de "capacidade negativa". Tomo este termo do poeta John Keats, que o definiu como a habilidade de ser "misterioso, incerto e duvidoso sem a limitação irritante do fato e da razão" (KEATS, J., 1986, p. 863). Vejo a reconfiguração poética do sagrado como algo que ocupa esta abertura, este espaço vazio; e não é algo confinado a Keats e ao Romantismo. É algo que vai de volta ao início da cultura, como Aristóteles reconheceu, em A Poética, quando ele define o drama como um movimento catártico de ida e volta entre compaixão e medo.

Se a compaixão (eleos) é a identificação com o sofrimento representado no palco, o medo (phobos) é a retirada ou a recusa à participação. Crença torna-se quase-crença. Tragédia, como Nietzsche e outros nos lembram, deriva, originalmente, de cultos sacrificiais dionisíacos; mas na transposição do rito religioso à representação dramática, uma mudança radical acontece. O resultado da mythos-mimeses (enredo-redescrição) ocorre na transformação do literal em figural. O termo 'tragédia' significava originalmente "cabeça de cabra" [Goats Head], porque muitos protagonistas usavam máscaras que representavam animais sacrificados, eram eles mesmos os pharmakoi, os homens-deuses sacrificiais (como Dionísio) que teriam sido celebrados nos cultos antigos. Em outras palavras, a mudança para a imitação dramática abriu um espaço ficcional de "como se" onde nós suspendemos nossa "crença" nos deuses e nossa "descrença" na ficção.

abraâmicas ao longo dos séculos. Algo verdadeiro, eu suspeito, para todas as religiões. Sem fé é dispensado, mais puro do que puro. Não há hospitalidade que não seja replicada pelo demônio negro da hostilidade. É por isso que anateísmo é sempre uma chamada de retorno para renovações e recuperações do momento inaugural da graça e do bem, em todos os momentos potenciais. Não há hospitalidade de uma vez por todas. A hostilidade é uma traição contínua da primeira promessa de hospitalidade - o momento criativo inaugural repetido nas histórias de Abraão, Jacó, Moisés, Cristo, etc. e em cada instante de nossas vidas cotidianas. Hostilidade violência, intolerância, medo, agressividade, egoísmo - é uma tentação constante para teístas e ateus da mesma forma que precisa ser superada de novo e novamente em atos "em-seguimento" [aftering], de retorno e recuperação do momento inaugural da hospitalidade que nós testemunhamos nas grandes histórias de ruptura e novo começo. A civilização começa com o aperto de mão: a escolha de estender a mão aberta, em vez de estender a espada. Como diz Emmanuel Levinas, o rosto do estranho em sua nudez apresenta o rastro de Deus: o pobre, a viúva, o órfão e o estrangeiro. Conferir: LEVINAS, E. Totality and Infinity, transl. by A. Lingis, Duquesne University Press, Pittsburgh, 1969.

9 Cf. KEARNEY, R. Anatheism, cit. 
Ou, para citar Coleridge, nós "voluntariamente suspendemos nossa descrença" no imaginário, a fim de agir como se acreditássemos nos personagens fictícios ${ }^{10}$. Isto requer uma simultânea e igual disposição de descrença na religião - na medida em que esta última implica pretensões de verdade. Por isso, assistimos as grandes tragédias gregas - que narram o sacrifício de Édipo, Efigênia, Antígona e assim por diante - certos de que os atos religioso-ritual-sacrificiais que ocorrem no palco não têm quaisquer pretensões à "realidade" enquanto tal. Nós assistimos à peça como se os deuses estivessem presentes diante de nós, mas sabemos muito bem que eles não estão. O figural substituiu o literal. Agora, é esse desvio pelo reino do como-se - onde todos os tipos de possibilidades podem ser explorados em uma "variação da imaginação livre" - que permite uma atitude de disposição anateísta. Nós suspendemos nossas crenças religiosas (pelo menos provisoriamente) ao entrar no teatro, a fim de sermos capazes de acreditar no teatro de faz de conta. Isso, como leio, é um prenúncio aristotélico da habilidade negativa de Keats (e, neste sentido, a suspensão fenomenológica de Husserl). A saber: a liberdade agnóstica para explorar todos os tipos de diferentes pontos de vista e atitudes sem as restrições da ortodoxia, da moralidade ou da censura. Mas isso não é o fim para o anateísmo. Uma vez que saímos do teatro, uma vez que se suspende o desvio poético do teatro, encontramo-nos novamente no mundo real vivido com a opção de acreditarmos ou não nos deuses. Mas, sem essa capacidade negativa - como uma forma de licença poética - fica difícil escolher livremente qual, se houver, "declaração de verdade" religiosa aderir. Compromissos de fé autênticos são mais garantidos, talvez, por hiatos da estética do ateísmo que contém, dentro de si, a opção anateísta e reanima o sentido real do drama existencial na relação entre o divino e o humano. Uma espécie de abandono ainda que provisório, momentâneo, hipotético - das crenças recebidas é algo que considero fundamental para a re-imaginação do sagrado. E a possibilidade da fé genuína, como nos lembra Dostoievski, sai do 'calvário da dúvida'.

Então, como é possível relacionar a hipótese da suspensão da crença com a literatura contemporânea? Em Anatheism, vejo Joyce, Woolf e Proust como três escritores modernistas que "re-imaginaram o sagrado". Em Ulysses, temos Stephen respondendo à questão "O que é Deus?" com a resposta: "Um grito na rua" ${ }^{11}$. (O barulho da rua recuperado no grito de Molly, no final do livro). Theos é ecoado como eros. Mas o que Joyce quer dizer quando ele descreve Deus como um 'grito na rua'? Qual é o sentido do sacramental, da Eucaristia,

10Cf. COLERIDGE, S.T. Biographia Literaria, Claredon Press, Oxford, 1907.

11 Cf. JOYCE, J. Ulysses, Penguin, London, 1968. 
do sagrado, que Joyce está trazendo à tona nessa frase e na constante revisitação e reescrita da gramática da transubstanciação ao longo do livro? Há toda uma série de eucaristias - Missas negras, Missas paródicas, Comunhões fracassadas - e então, finalmente, temos a recuperação da própria Molly como "grito na rua": seu "Sim" decisivo, seguido da lembrança da troca do bolo de sementes com Bloom, seu beijo na cabeça de Howth. Não é este um poderoso exemplo do que Joyce chama de "epifania"? O sagrado na origem do profano? O infinito no infinitesimal? O sacramental no cotidiano?

Acredito que há também epifanias poéticas na obra Ao Farol de Virginia Woolf. A minha pergunta é: o que Lily Briscoe quer dizer quando fala sobre pequenos milagres diários, "fósforo aceso na escuridão" 12 , iluminações comuns? O que está acontecendo no texto? E qual relação tem Lily com a Sra. Ramsay, que prepara e realiza um banquete quase-Eucarístico na primeira parte do livro, que é seguido por um "interlúdio" de desencanto, de morte e guerra, antes de voltar à pincelada final de Lily, que completa seu retrato da Sra. Ramsay - "está terminado" (WOOLF, 1990, p.207) - na terceira parte do livro? Não estaria Lily Briscoe recuperando, de alguma forma, a experiência perdida do banquete de abertura, anateísticamente? Não é somente quando Lily tem de deixar a mística da $\mathrm{Sr}$. Ramsay - após sua morte e desaparecimento - que ela consegue ressuscitá-la em seu retrato? O que "Está terminado" (como ela completa sua pintura) significa? Em que sentido está terminado? O que significa, exatamente, para Lily se envolver no gesto sacramental da memória eucarística? (WOOLF, 1990, p.207).

E, finalmente, o que Proust quer dizer com o pequeno milagre em Em busca do tempo perdido? Aqui, encontramos novamente linguagem de repetição sacramental, transubstanciação, ressurreição, epifania. O retorno da "experiência inexperienciada", como uma segunda experiência, uma ana-experiência em um ana-tempo (o tempo reencontrado). Tenho em mente as várias recuperações dos momentos perdidos, quando Marcel visita o salão de Guermantes ao final do romance - o tropeço nos paralelepípedos, o tilintar dos talheres, a leitura da história de George Sand e assim por diante. Quais são esses momentos passados que, repetidos, retornam como epifanias que lhes abrem um novo futuro (o encontro com a filha de S. Loup)?

O que querem os três autores (Joyce, Woolf e Proust) - que eram declaradamente ateístas, agnósticos e apóstatas - ao abrirem um espaço imaginário para re-escreverem a gramática da transubstanciação? Interessa-me explorar aqui esta relação entre imaginação e fé - fé como aposta, liberdade, narrativa, em-

12 Cf. WOOLF, V. To the Lighthouse, Harcourt Brace, London, 1990, p. 92. 
patia. E isso é mais do que um jogo de palavras. Minha aposta é a de que o jogo da linguagem sacramental em certos artistas e escritores (Joyce, Woolf, Proust, Keats, Hopkins, etc.) abre um espaço sacramental da experiência: um mundo textual da epifania. E como me ensinou meu mentor filosófico, Ricoeur: se a escrita é o movimento da ação ao texto, a leitura é o movimento do texto de volta à ação. Movemo-nos em um círculo hermenêutico da prefiguração existencial à configuração textual à reconfiguração existencial (a apropriação do leitor do texto em sua vida). Nesta odisseia do autor através do texto para o leitor podemos testemunhar algumas possibilidades de transfiguração: a saber, a conversão de Poder-Ser em poder ser novamente [from the Powers-That-Be to the power to be anew]. Ou, o que nomeio, a abertura para o chamado transformador do Outro.

Deixe-me dar um último exemplo de re-imaginação do sagrado. No segundo capítulo de Anatheism, revisito a cena primária do evento Cristão - A Anunciação. Faço-o não apenas teologicamente, mas poeticamente. Por quê? Porque acredito que a Anunciação, assim como temos recebido ao longo do tempo e da história, é em grande parte uma cena de imaginação religiosa, no sentido mais profundo do termo: um primeiro cenário anateísta que pode ser revisitado em imaginações poéticas que podem levar a uma nova fé. Para ser mais preciso, me surpreende que as formas mais eficazes de voltar a este evento fundador do cristianismo sejam feitas por poetas e pintores (em vez de pregadores e teólogos). O texto de Lucas tem apenas algumas linhas, mas temos inúmeros poemas sobre a Anunciação ao longo dos séculos - e, mais recentemente, versos extraordinários como os de Denise Levertov, Andew Hudgins e Kascha Semonovitch, etc. ${ }^{13}$ - que exploram o momento inicial quando Maria encontra o estranho em Nazaré e pondera se ela vai dizer sim ou não. Assim como Kierkegaard entra na mente de Abraão em Temor e Tremor (uma obra teo-poética, se alguma vez houve uma), e Kazantzakis entra na mente de Cristo em A Última Tentação de Cristo $^{14}$. Estes e outros poetas realizaram com maestria a imaginação de grandes figuras sagradas. (Também encontramos essa prática nas tradições não-abraâmicas, como as encantadoras narrativas de Jataka sobre a vida de Buda de Ajanta e Ellora). Para retornar à Anunciação, podemos dizer que várias releituras poéticas desta cena nos convidam a recuperar "anateísticamente" o momento de oscilação de Maria: a sua ponderação de descrença e crença como ela responde ao chamado do estranho. Fazemo-lo após o evento - dois mil anos depois - por meio da imaginação. Em suma, revisitando essas imagens revi-

13 Conferir nossa discussão sobre estes poetas em: KEARNEY, R. Anatheism, pp. 23-25.

14Cf. KAZANTZAKIS, N. The Last Temptation of Christ, Trad. P. A. Bien, Simon \& Schuster, New York, 1998. 
vemos os dramas primordiais como se estivéssemos lá, como se estivéssemos encontrando essas figuras sagradas pela primeira vez.

E como se não bastassem os poetas, também temos os pintores. Inúmeros deles - de Botticelli e da Messina a Rembrandt, Rouault e Sheila Gallagher! ${ }^{15}$ O que a imaginação artística faz aqui é nos convidar de volta para os momentos inaugurais da fé para que possamos vivê-los "de novo, novamente" - no tempo (linguagem) e no espaço (pintura). Sem tais imaginações ana-teístas tudo o que temos é dogma seco e doutrina abstrata: ambos sem vida. Mas nesta re-leitura anateísta do momento da aposta de Maria, descobrimos que ele também foi um momento anateísta. A própria Maria foi envolvida em um ato de recuperação (passado) e promessa (futuro) anateísta. Ela também foi pega em um círculo hermenêutico de passado e futuro, antes e após Deus. O fato de que a moça de Nazaré (que prefiro chamar Nazarena, já que no momento da aposta ela não é mais Maria e ainda não é Madonna) ser quase sempre retratada lendo em um átrio, indica, creio, que ela está recordando as narrativas de sua fé abraâmica e as várias apostas que seus antepassados fizeram quando solicitados pelo chamado divino, por anjos disfarçados - desde Abraão e Jacó até Tobias e Samuel ${ }^{16}$. A Nazarena revive o passado quando ela faz seu salto de fé para o futuro - escolher, livremente, acreditar que o impossível é possível, que ela vai conceber uma criança. Como Sara quando visitada por estranhos divinos, antes

15 Na pintura de Rembrandt "Emaús", Cristo é uma silhueta escura iluminando os dois discípulos com transmissão de luz de sua face invisível. O retorno do estranho messiânico permanece desconhecido, não importa quão familiar tenha sido a eles, durante sua vida anterior. No partir do pão em Emaús, Cristo está e não está ali, visto e não visto, reconhecido e irreconhecível, familiar e estrangeiro. Não há ponto final glorioso triunfal. Neste momento, que Ricoeur chama de 'hospitalidade eucarística', há sempre algo mais, outro, transcendente, excessivo, desviado. Tem sempre uma disputa de tradução e discernimento em curso. Nem uma única revelação saturada. Nem uma iluminação final. Nem alguma exposição ou divulgação total. Este é o porquê o momento anateísta repete constantemente a si mesmo em cada religião e de religião para religião. Porque é sempre algo estranho: Há um Deus após Deus, após Deus, após Deus... “Em-seguimento" ["Aftering"] sem parar, e, se isso acontece, você tem idolatria, triunfalismo, dogmatismo, fundamentalismo: guerra entre religiões e dentro de religiões. Isso é o quão próximo a aposta chega. Hospitalidade e hostilidade são gêmeas etimologicamente do termo hostis, que significa tanto "inimigo" quanto "hóspede": a face de Janus que se pode olhar de qualquer lado. Ana- sinaliza um lugar e tempo de limiares, limites, bordas, cruzamentos; é por isso que Janus é o guardião das fronteiras, o santo padroeiro de traduções e transições - junto com Hermes e Paráclito. Esta duplicidade profunda que Emile Benveniste identifica nas raízes indo-europeias de ambos, hóspedes e hostis, em toda forma de retorno e até o fim. Cf. BENVENISTE, E. Indo-European Language and Society, Faber and Faber, London, 1973, pp.71-78.

160 momento anateísta de ponderar, pesar e apostar, também é indicado pelo fato de que em quase todas as cenas da Anunciação, Maria está geralmente lendo em um púlpito. Isto sugere que ela se inscreve numa tradição narrativa do Livro: ela está revisitando e recuperando histórias e memórias daqueles que vieram antes dela. Talvez Abraão e os estrangeiros em Mamre? Ou Jacó encontrando Raquel no poço? Ou Salomão e a mulher Sulamita? Quem sabe. Mas, seja qual for o texto, ela está imersa, certamente, em sua preparação hermenêutica - através da linguagem, da narrativa, da memória - para este encontro com o estranho. Eu digo preparar no sentido de predisposição, não predeterminação, porque Maria é totalmente livre para romper com essas narrativas, ou para voltar a elas, transformando-as em direção a uma nova abertura. 
dela. Este momento de livre escolha, recordar o passado e antecipar o futuro, é um caso primordial de ana-tempo do ana-teísmo: neste instante oscilante, onde a eternidade paira sobre o aqui e agora, Maria está diante das opções de crença e descrença. É-nos dito em Lucas que, neste momento anateísta de liberdade, ela "estava preocupada e ponderou"17. É algo difícil. Muito se passa em sua cabeça. O termo grego para ponderar é dialogizomai: ela dialoga com o estranho visitante, consigo mesma, com todas as vozes em sua cabeça, dizendo "faça isso, não faça isso". Para além desta confusão de perspectivas e possibilidades, ela escolhe. Além disso, diria que, se ela não escolhesse, ou não fosse livre para escolher, a partir de um espaço de capacidade negativa, de empatia imaginativa e abertura para o outro, a aposta teria sido falsa. A encarnação seria um ato de violação divina. Teísmo sem anateísmo é apenas isso - uma violação da verdade e da liberdade humana. Mas também é importante reconhecer que esta ponderação, este em-seguimento [aftering], este drama de aposta, de responder ao chamado, é carnal. É pensar novamente na carne. Isso acontece em um instante, é uma hermenêutica encarnada fundada radicalmente por esta aposta. Nem uma resposta reflexa a um estímulo nem um cogito desencarnado com uma ideia clara e distinta! Maria pensa por meio do corpo e incorpora seu texto em ação. Por isso, se - em quase todos os retratos - ela tem um livro em uma das mãos, ela tem um lírio (representando os sentidos) na outra. A resposta de Maria a Gabriel é uma das mais perspicazes - um conhecimento sensitivo, um pensamento que é também toque e teste, sapientia como sapere-savourer-savoir.

Re-imaginar o sagrado nos faz reavivar a fé - tornar vivo novamente (re-viver). A imaginação religiosa pode, creio, nos trazer de volta para o momento e nos permite trazer o momento de volta em nossas vidas novamente. Tornamo-nos contemporâneos dramáticos da aposta. Isso é ana-teísmo. Se a fé precisa de seus profetas, ela também precisa de seus poetas ${ }^{18}$.

17Cf. Lucas 1, 19. 'Perplexo' ['Dietarachthe'], 'perturbado' é o termo usado na Bíblia para responder aos mensageiros impossíveis com mensagens impossíveis. Sarah, a mãe de Sansão, os pastores de Belém, Maria.

18 Se profetas e pregadores nos dão a teologia, a pintura nos leva para dentro do corpo de Maria e a poesia para a sua imaginação. Sem o menor sinal de blasfêmia. Há um poema de Denise Levertov que fala do equilíbrio de Maria entre seu átrio (significando o pensamento) e o lírio (significando os sentidos) diante do visitante angelical que está de pé e paira, e que ela reconhece como um convidado, um hóspede [hospes]. A última estrofe diz:

"Falam-nos da obediência dócil. Ninguém menciona a coragem.

O espírito desperta

não entra nela sem consentimento.

Deus espera.

Ela é livre para aceitar ou recusar; escolha intrínseca humana" (APUD Kearney, R. Anatheism, cit., p.24) 


\section{O Sagrado - Uma Questão de Estranheza}

O "sagrado" está em algum lugar entre o "espirituoso" e o "religioso". Muitas vezes ouvimos a frase: "Sou espirituoso, mas não religioso". E temos ouvido pessoas dizerem que uma determinada pessoa, lugar, coisa ou momento é "sagrado" para eles. O "espiritual" pode incluir o "sagrado" e o "religioso", mas também pode operar independentemente deles. "Espírito" é uma categoria muito ampla que, às vezes, pode significar qualquer coisa e tudo. Mas na maioria das vezes isso significa alguma coisa e, na verdade, algo importante.

Sabemos como em nossa própria era secular ainda há muitas pessoas que anseiam por "algo" (elas sabem bem o que, algo, "no entanto, que pode ser definido"). Isso é referido, muitas vezes, como uma "busca espiritual" e pode expressar-se em uma grande variedade de formas, desde a apreciação da arte de Botticelli, Bach ou Bob Dylan até movimentos teosóficos New Age, leituras astrológicas ou formas mais recentes de meditação transcendental e ioga - uma mistura de Rumi e Ramakrishna. Todas estas formas de jornada espiritual e autodescoberta podem ocorrer sem qualquer compromisso com a fé religiosa confessional, com ritos, credos, práticas e doutrinas herdadas.

Assim, o "espiritual" pode envolver uma busca que não envolve necessariamente a religião; se pela religião entendemos um conjunto específico de alegações de verdade, credos, tradições rituais compartilhadas e códigos de comportamento institucionais. O "sagrado", por outro lado, reside, sugiro, em algum lugar entre o espiritual e o religioso. Difere do espiritual por ser algo que você encontra em vez de algo que você procura. Está "fora daqui" em algum lugar, em vez de aqui, por assim dizer. Está lá antes que você saiba que ele está lá. Antes da autoconsciência. Antes de saber. Antes da epistemologia. Diria que: não conhecemos o sagrado, nós o re-conhecemo-lo.

Deixe-me dar alguns exemplos. Falamos sobre coisas que são sagradas para nós. Certas pessoas, como mencionei, podem ser sagradas para nós (Penso na "epifania do rosto" de Levinas onde o outro, diante de mim, torna-se totalmente único e insubstituível). O tempo também pode ser sagrado para nós, sinalizando um kairos específico (antes-tempo e depois-tempo) que, como se sabe, supera o chronos (o tempo secular linear de um momento após o outro). Enquanto o tempo sagrado é uma coisa "por causa" (dia) de outra; o tempo comum é uma

Esses versos indicam que não há imposição cega do Destino divino. O sim de Maria não é um mero "efeito" de alguma Causa onipotente ou Vontade sobrenatural que prevalece inelutavelmente, aconteça o que acontecer. Ela não é uma presa passiva de um Alfa-Deus. A Nazarena podia recusar ou aceitar, ela estava livre para dizer sim ou não. Ela disse sim. E se ela tivesse dito não, não teria havido cristianismo. 
coisa que sucede (meta) a outra. O primeiro é sobre estar em tempo [in time], e o último no tempo [on time]. O calendário litúrgico - Advento, Natal, Epifania, Quaresma, Páscoa, Dia de Todos os Santos - oferece exemplos tradicionais de tempos sagrados na cultura cristã. E, além de pessoas e tempos, lugares também podem ser sagrados, como khora - um espaço especial tradicionalmente separado do espaço profano unidimensional ${ }^{19}$. Então, em todos os três casos, de pessoas, tempos e lugares, o "sagrado" se refere a algo afastado. Algo estranho e inefável. Walter Benjamin se refere a esta extra dimensão como "aura". Sacer em Latim tem a mesma raiz de secreta ou segredo, que por sua vez é uma tradução do Grego mysterion, que significa "vendado". Então, o sagrado é algo que nos surpreende; algo que não temos construído ou previsto com antecedência, como pontos-cegos, por assim dizer. É, nas palavras de Virginia Woolf, a "coisa deixada não feita" (WOOLF, 1990, p.118). Em outras palavras, o sagrado, em sua forma mais básica, envolve um sentido profundo de que há algo "mais", algo radicalmente Outro, misterioso, transcendente. É impossível para nós imaginá-lo antes de re-imaginá-lo de novo, antes de tornarmos o impossível possível, não obstante um salto de fé. O sagrado é a percepção de que há algo que é maior do que o "eu". Ou maior do que "nós", entendido como um consenso imanente do "nós". Claro que eu poderia dizer muito aqui sobre a noção de sacer como algo ou alguém numinoso [numinous] e de inspiração ambivalente "temor e tremor" (Kierkegaard), "fascinação e horror" (Otto), "Totem e Tabu" (Freud), "bênção e maldição" (Caillois). Em suma, a pessoa sacra é o Estrangeiro que ultrapassa as noções normais da lei e da lógica, quebrando nossos horizontes convencionais, perspectivas e pressupostos. É o "outro" na outra pessoa que nos precede e excede. E como meu mentor, Paul Ricoeur, costumava dizer, donne à penser: dá origem ao pensamento, provoca e amplifica a nossa razão e compreensão. (Não sou defensor de irracionalismo cego e fideísmo).

O que estou tentando sugerir agora com a noção de anateísmo é que o sagrado também pode ser experienciado no e pelo secular. Para mim, o hífen entre sagrado e secular é absolutamente crucial. Assim, a este respeito, anateísmo é uma tentativa de sacralizar o secular e de secularizar o sagrado. Re-imaginar o sagrado após o secular e no secular. Bonhoeffer fala sobre estar com Deus e ainda viver sem Deus. Chamo esse duplo sentido do "com e sem", o movimento de adeus. Esse duplo movimento envolve um momento ateu e teísta e supera ambos. Em seu disfarce ateu, a-deus é uma partida, um abandono, uma despedida, ao antigo Deus de poder metafísico, ao Deus que pensávamos ter e conhecer, o 
Omni-Deus da soberania e da teodiceia. Adeus, portanto, ao Deus que Nietzsche, Freud e Marx declararam morto. Mas, ao dizer adeus ao Omni-Deus, o anateísmo abre a opção a um Deus que ainda está por vir. Ou um Deus que ainda está para voltar novamente. Se você perdoa o jogo etimológico dos prefixos - ana tem dois "a": um duplo "a" de $a b$ e $a d$. Mais precisamente, o $a b$-deo de partida de Deus abre a opção para o ad-deum de um retorno a Deus após Deus, um movimento suplementar em-seguimento [aftering] e de novo [overing]. Mas assim que o antes-e-após Deus torna-se fixo ou fixado, precisamos desconstruir este último fetiche e deixar "após Deus" novamente. E assim por diante, sem fim.

Em suma, o Deus ana-teísta é um perpétuo partir e chegar, conjuga a capacidade negativa com o renascimento constante do divino no ordinário. Este duplo sentido do sair e voltar está, para mim, no cerne do sagrado. E pode expressar-se tanto "espiritualmente" (como a abertura graciosa geral para "algo mais") ou "religiosamente" (envolvendo compromissos de credo e devoções). $\mathrm{O}$ anateísmo tem muitos edifícios. Uma pessoa pode ser anateísta teísta ou anateísta ateísta. Suspeito que muitos de nós somos, muitas vezes, um e outro alternadamente. Mas independente da forma que assuma, anateísmo é uma aposta existencial para saltar ou não saltar, acreditar ou não acreditar. Com temor e tremor. Com incerteza e mistério. Deixe-me terminar com esta descrição de Anatheism da relação entre o secular e o sagrado:

\begin{abstract}
Anateísmo não é um ateísmo que deseja livrar o mundo de Deus, rejeitando o sagrado em favor do secular. Nem é um teísmo que procura livrar Deus do mundo, rejeitando o secular em favor do sagrado. Nem é, finalmente, um panteísmo, antiga ou nova era, que combina o secular e o sagrado em um, negando qualquer distinção entre o transcendente e o imanente. O Anateísmo não diz que o sagrado é o secular, ele diz que é no secular, através do secular, em direção ao secular. Iria ainda mais longe para dizer que o sagrado é inseparável do secular, permanecendo distinto. Anateísmo fala de inter-animação entre o sagrado e o secular, mas não de fusão ou confusão. Eles são intrinsecamente interligados, mas nunca a mesma coisa (KEARNEY, R. p.166).
\end{abstract}

O ana- de anateísmo garante que o Deus que já veio esteja sempre ainda por vir. 
BENVENISTE, E. Indo-European Language and Society, Faber and Faber, London, 1973.

CAMARGO, L. Tradução comentada da Poesia e da Prosa de Gerard Manley Hopkins. Campinas, Universidade Estadual de Campinas, 1993. (Dissertação)

COLERIDGE, S.T. Biographia Literaria, Claredon Press, Oxford, 1907.

ELIADE, M. The Sacred and the Profane, Trad. W. R. Trask, Harcourt, Orlando, 1959.

JOYCE, J. Ulysses, Penguin, London, 1968.

KAZANTZAKIS, N. The Last Temptation of Christ, Trad. P. A. Bien, Simon \& Schuster, New York, 1998.

KEARNEY, R., Debates in Continental Philosophy: Conversations with Contemporary Thinkers, Fordham University Press, New York, 2004;

Anatheism: Returning to God after to God, Columbia University Press, New York, 2010;

Derrida's Messianic Atheism, in E. Baring and P. Gordon (ed.), The trace of God: Derrida and Religion, Fordham University Press, New York, 2014.

KEATS, J., Norton Anthology of Literature, Norton, New York, 1986.

KIERKEGAARD, S., Fear and Trembling, Transl. by A. Hannay, Penguin, New York, 1985.

LEVINAS, E. Totality and Infinity, transl. by A. Lingis, Duquesne University Press, Pittsburgh, 1969.

RICOEUR, P. The Symbolism of Evil, Trad. E. Buchanan, Beacon Press, Boston, 1968;
.Relgion, Atheism, Faith. in: The Conflict of Interpretations, ed. D. Ihde, Northwestern University Press, Evanston, 1974.

WOOLF, V. To the Lighthouse, Harcourt Brace, London, 1990. 